\section{Australian Journal of \\ Crop Science}

\title{
Rehabilitation of pasture fertilized with wood ash and its application management in the Brazilian Cerrado
}

\author{
Éllen Souza do Espírito Santo ${ }^{1}$, Edna Maria Bonfim-Silva* ${ }^{1}$, Helon Hébano de Freitas Sousa ${ }^{1}$, Tonny José \\ Araújo da Silva ${ }^{1}$, Adriano Bicioni Pacheco ${ }^{1}$, William Fenner ${ }^{2}$
}

\author{
${ }^{1}$ Federal University of Mato Grosso - UFMT, Institute of Agricultural and Technological Sciences, 5055 Students \\ Avenue Rondonópolis, 78.735-901, Brazil \\ ${ }^{2}$ Federal University of Mato Grosso - UFMT, Faculty of Agronomy and Zootechnic, 2367 Fernando Corrêa da Costa \\ Avenue, Cuiabá, 78060-900, Brazil
}

*Corresponding author: embonfim@hotmail.com

\begin{abstract}
The degradation of pastures generates economic, social, and especially environmental damages, as it increases the need for the opening of new areas. In addition, the destination of the residue from the combustion of vegetal biomass is becoming a problem in areas of great industrial production. This study aimed to evaluate biometric parameters and chlorophyll index of Marandu grass pasture under rehabilitation using wood ash doses and application managements. The experiment was conducted in randomized blocks, in a $6 \times 2$ factorial arrangement in strip plots, consisting of six doses of wood ash $\left(0,3,6,9,12\right.$ and $\left.15 \mathrm{Mg}^{-1}\right)$ and two application managements (incorporated to the soil with light-duty disc harrow and not incorporated), with four replicates. To standardize the initial experimental conditions, the pasture was cut at average height of $0.15 \mathrm{~m}$ using a mechanical mower, followed by manual removal of the cut material. The biometric parameters evaluated were plant height, number of leaves and number of tillers, besides chlorophyll index. In general, when significant difference was found for wood ash doses, the best results of biometric parameters and chlorophyll index were observed between the doses of 8 and $15 \mathrm{Mg} \mathrm{ha}{ }^{-1}$. Regarding wood ash application management, highest values of plant height were found in the management with incorporation, whereas the management without incorporation was responsible for highest numbers of leaves and tillers.
\end{abstract}

Keywords: Brachiaria brizantha; biometric parameters; chlorophyll index; waste disposal.

Abbreviations: A_Application; CAPES_Coordenação de Aperfeiçoamento de Pessoal de Nível Superior; CEC_Cation exchange capacity; Cl_Chlorophyll index; CNPq_Conselho Nacional de Desenvolvimento Científico e Tecnológico; D_Doses; EMBRAPA_Empresa Brasileira de Pesquisa Agropecuária; FAPEMAT_Fundação de Amparo à Pesquisa do Estado de Mato Grosso; IMA_Cotton Institute of Mato Grosso; NL_Number of leaves; NT_Number of tillers per $\mathrm{m}^{2}$; O.M._Organic matter; PH_Plant height; PN_Neutralizing power; Res_Residual; SB_Base sum; SPAD_Soil Plant Analysis Development; V_Base saturation; WA_Wood ash.

\section{Introduction}

Pasture systems are an important source of income generation and cattle production, and currently the form most widely used for bovine production. Given the significant increase in food demand, due to the growth in the global population, it becomes necessary to increase beef and dairy cattle production efficiency. In this context, maintaining the yield of tropical grasses is one of the greatest challenges for livestock farmers in Brazil and worldwide, especially in the Amazon biome, since degradation processes favor the reduction of organic matter and phosphorus availability over time (Fonte et al., 2014) and soil structure degradation (Nesper et al., 2015).

The most used forage grass species in Brazil are those in the Brachiaria genus, with about $85 \%$ of the total cultivated area, due to their good adaptability to various edaphoclimatic conditions. Evaluations of pasture production and perenniality are related to the development and growth of leaves and tillers, which highlights the importance of monitoring and employing techniques to increase the dimensions of plant organs within a certain period, and it is possible to quantify plant development through biometric parameters (Salisbury and Ross, 1992). Pasture production is influenced by the correction of soil fertility levels, especially in Brazil, where soils are characterized by having limited natural fertility (Soares Filho, 2010), besides the poor management over time.

Neosols occupy approximately $15 \%$ of the Brazilian territory and are characterized by high sand percentage and low natural fertility. For requiring more corrections, these soils are commonly used to implement pasture systems and, if properly managed, they can provide nutrients and adequate support. However, such management requires specific care with respect to the characteristics of this soil class (EMBRAPA, 2013). Using organic wastes in these areas can be an alternative for the corrections needed. Research studies have demonstrated the potential of using these 
wastes in pastures, but this potential needs to be confirmed in the long term (Bougnom et al., 2012).

The benefits of ash application are well established, but it is necessary to delimit its range of use and the type of management leading to highest effect (Bougnom et al., 2012). One of the main benefits of wood ash is the potential to neutralize soil acidity, besides the supply of nutrients, especially potassium and phosphorus. In tropical soils, ash application led to chemical changes in the soil similar to those caused by liming in experiment under controlled conditions, such as higher cation exchange capacity (CEC), reduction of $\mathrm{Al}$ toxicity and neutralization of soil acidity (Huotari et al., 2015; Qin et al., 2017). Ash application effects vary according to the type of soil. Nonetheless, research studies suggest that using ash does not result in damages to soil mesofauna and there are even indications that it is less toxic than liming with respect to the effect of $\mathrm{pH}$ elevation on soil mesofauna development and reproduction (Qin et al., 2017).

Most studies on the use of ash report its application in forests and under temperate climate (Huotari et al., 2015), which significantly differ from the conditions in the present study, tropical climate with ash application in soils of lower fertility and pasture in stage of degradation.

The increasing amount of wastes generated by the use of wood in boilers as source of energy leads to the need for new technologies to provide adequate disposal, avoiding environmental damages. Wood ash utilization in agriculture is a feasible alternative for the disposal of this type of waste because, besides the environmental benefits, it has nutrients that are essential to plant development, thus reducing the use of mineral fertilizers and financial costs (Bezerra et al., 2016).

Given the above, the objective was to test whether the form and dose of wood ash application in degraded pasture lead to improvement of biometric quality and chlorophyll index in Marandu grass.

\section{Results and discussion}

\section{Overview of key results}

In general, the interaction between wood ash doses and application managements (incorporated with light harrow and not incorporated) had no effect on the biometric parameters of Marandu Grass in the first two years of evaluation, except on plant height in the third and fourth evaluations of 2015 and second evaluation of 2016. For the other variables, wood ash dose has greater influence than its application management. Number of leaves and number of tillers in both years were the variables most affected by wood ash doses and forms of application.

\section{Chlorophyll index}

In the first evaluation year, there was no significant difference in the chlorophyll index between treatments in the first and fourth evaluations, and the mean values were equal to 38.62 and 41.17 , respectively. In the second evaluation, 2015, only wood ash doses had effect on chlorophyll index, which fitted to a linear regression model, leading to $12 \%$ increment between the highest dose within the experimental range and the treatment under no ash application (Figure 1).

In the third evaluation of 2015, only application form had effect on chlorophyll index, which was equal to 42.86 when ash was incorporated and to 47.12 when ash was not incorporated.

Chlorophyll index in the second year did not differ statistically between treatments in any of the evaluations and the values were equal to $42.5,60.8,40.0$ and 30.50 for the first, second, third and fourth evaluations, respectively. Lack of effect may be linked to Marandu grass rusticity features, even in stage of degradation, and to the short evaluation period (two years), which does not yet show the effects of wood ash doses and application managements on chlorophyll index. Bonfim-Silva et al. (2014) observed benefits of the nutrition in forage grasses when fertilized with wood ash in Oxisol.

SPAD values for Marandu grass in good nutritional state are expected to be higher than 30 units. In the present study, all wood ash doses led to adequate levels in the Marandu grass, indicating a good nutritional status. For the nitrogen contents, which are related to chlorophyll index, another determinant factor is the availability of organic matter in the soil, influenced by the pedogenetic characteristics and grass management over time (Abreu and Monteiro, 1999).

Likewise, Lavres Júnior and Monteiro (2006), studying Marandu grass in nutrient solution and at different growth stages, observed quadratic response in the SPAD index (54.03) at 35 days of growth, at the $\mathrm{N}$ dose of $267 \mathrm{mg} \mathrm{L}^{-1}$. Both diverge from the present study, which found linear response of chlorophyll index in the first year of rehabilitation and no differences in the second year in any of the evaluations. Quadratic fits were obtained in Marandu grass plants under wood ash doses in Oxisol (Santos et al., 2014). Such response may be associated with the initial fertility of the soil, organic matter content, $\mathrm{N}$ fertilization management and type of soil. Despite the lack of effect on chlorophyll index, ash application leads to benefits for grass nutrition and is a potential alternative source as fertilizer (Bezerra et al., 2014).

Costa and Queiroz (2013) highlight the importance of indirect and instantaneous methods to determine the nutritional status of crops like pasture in the field, since the decision-taking also depends on factors such as the response time.

\section{Plant height}

In the first year of evaluation, Marandu grass height in the first cut was only affected by wood ash application management, with value of $36.68 \mathrm{~cm}$ when incorporated and $26.68 \mathrm{~cm}$ when not incorporated.

In the second cut, plant height did not significantly differ between treatments and its average value was $55.03 \mathrm{~cm}$. Plant height was affected by the interaction between wood ash doses and application forms in the third cut of the Marandu grass. It can be observed that plots in which wood ash was incorporated to the soil showed the highest means of plant height, for all doses, in comparison to the management with no incorporation. Highest mean of plant height $(55.24 \mathrm{~cm})$ was obtained with the highest dose within the experimental range $\left(15 \mathrm{Mg} \mathrm{ha}^{-1}\right)$ when wood ash was 
incorporated to the soil using a light-duty disc harrow (Table 1).

When wood ash was incorporated, plant height fitted to a linear regression model, reaching value of $53.18 \mathrm{~cm}$ at the highest dose within the experimental range. Lower values of plant height were found when wood ash was not incorporated, and the data fitted to a quadratic regression model, with maximum value $(35.90 \mathrm{~cm})$ at the dose of 9.86 $\mathrm{Mg} \mathrm{ha}^{-1}$ (Figure 2A).

In the fourth evaluation of the first year, there was interaction between treatments for plant height, and differences between managements were found at doses of 9 and $12 \mathrm{Mg} \mathrm{ha}^{-1}$. The values were respectively equal to 38.78 and $37.60 \mathrm{~cm}$ when the ash was not incorporated to the soil (Table 2).

For the fourth cut in the first year of evaluation, there was interaction between the studied factors and plant height data fitted to a quadratic regression model when wood ash was incorporated to the soil, with maximum of $43.06 \mathrm{~cm}$ at the dose of $11.70 \mathrm{Mg} \mathrm{ha}{ }^{-1}$. When the ash was not incorporated, plant height data fitted to a linear regression model, with value of $40.02 \mathrm{~cm}$ at the dose of $15 \mathrm{Mg} \mathrm{ha}^{-1}$, which represents an increment of $7.31 \%$ compared with the treatment under no wood ash application (Figure 2B).

In the second year of evaluation, plant height showed different responses in each cut. In the first cut, significant differences were individually caused by wood ash doses and application managements, in which the lack of incorporation led to taller plants $(30.61 \mathrm{~cm})$ compared with the incorporation $(24.96 \mathrm{~cm})$.

For wood ash doses in 2016, plant height data fitted to a linear regression model and its highest value $(36.37 \mathrm{~cm})$ was obtained at the highest dose within the experimental range $\left(15 \mathrm{Mg} \mathrm{ha}^{-1}\right)$, an increment of $47.24 \%$ in comparison to the treatment under no wood ash application (Figure $3 \mathrm{~A}$ ).

In the second evaluation, there was interaction between the studied factors, and wood ash incorporation did not differ statistically from the non-incorporation at the dose of $9 \mathrm{Mg}$ $\mathrm{ha}^{-1}$ and in the absence of fertilization. Highest value of plant height $(20.75 \mathrm{~cm})$ was found at wood ash dose of $15 \mathrm{Mg}$ ha' 1 , incorporated to the soil (Table 3).

Plant height as a function of wood ash doses fitted to a linear regression model for non-incorporated application and to a quadratic model for the incorporated application, with maximum values of $17.23 \mathrm{~cm}$ (dose of $15 \mathrm{Mg} \mathrm{ha}^{-1}$ ) and $20.32 \mathrm{~cm}$ (dose of $13.32 \mathrm{Mg} \mathrm{ha}^{-1}$ ), respectively (Figure 3B). In the third cut of the second year of evaluation, significant difference in plant height was only caused by wood ash doses and its highest value $(26.84 \mathrm{~cm})$ was observed the dose of $11.65 \mathrm{Mg} \mathrm{ha}^{-1}$ (Figure 3C).

In the fourth evaluation of the second year, significant difference in plant height was also caused only by wood ash doses. The data fitted to a linear regression model and maximum plant height $(27.55 \mathrm{~cm})$ was found at the highest dose (15 Mg ha ${ }^{-1}$ ), an increment of $22.44 \%$ compared with the control (Figure 3D).

In general, lack of significance by treatments in the characteristics evaluated in the first year may have been caused by the irregular rainfall distribution after wood ash application. Cumulative rainfall was equal to 170.20 and $74.00 \mathrm{~mm}$ in December 2014 and January 2015, respectively. On the other hand, in December 2015 and January 2016 the cumulative values were 125.40 and $256.20 \mathrm{~mm}$, respectively, a difference of $137.40 \mathrm{~mm}$ in the period. Uniform rainfall distribution throughout a month is fundamental for constant solubilization and absorption of water and nutrients by crops. In addition, concentrated rains with high precipitation rates favor erosion and nutrient leaching.

From the third cut on, plant height was positively influenced, with values above $35 \mathrm{~cm}$, corroborating with Bezerra et al. (2016), who evaluated fertilization with wood ash in Marandu grass in a Cerrado Oxisol and found heights of up to $47.93 \mathrm{~cm}$. In the second year, with better rainfall distribution, wood ash application influenced plant height since the first cut. Residual effect from one year to the other may also have favored this behavior.

A study on Brachiaria decumbens pasture rehabilitation, using fertilization with macro- and micronutrients and forms of soil management, conducted in the field, found that fertilization has positive effects on the increase of plant height, whereas harrowing led to pasture degradation in comparison to the control, in which there was no soil turning (Soares Filho, 2010). This differs from the present study, in which the management with wood ash incorporation led to higher mean values of plant height compared with the management without incorporation. The technique of soil turning can be beneficial in the short term, favoring better aeration and decompaction of superficial soil layers. Nonetheless, it is not possible to state that this trend will continue over time, because frequent soil turning accelerates decomposition and tends to reduce soil organic matter, becoming detrimental to soil physical and biological quality.

\section{Number of leaves}

In the first year of evaluation, wood ash doses caused significant differences in the number of leaves, which fitted to a linear regression model in the four evaluations. In the first cut, 470.51 leaves $\mathrm{m}^{-2}$ were produced at the dose of 15 $\mathrm{Mg} \mathrm{ha}{ }^{-1}$, an increment of $48.90 \%$ in comparison to the absence of wood ash application (Figure 4A). In the second cut, the increment was $49.60 \%$, with 1699.86 leaves $\mathrm{m}^{-2}$ (Figure 4B). Leaf production was equal to 1088.82 leaves $\mathrm{m}^{-2}$ in the third cut (Figure 4C) and to 1710.71 leaves $\mathrm{m}^{-2}$ in the fourth cut (Figure 4D), equivalent to increments of 46.66 and $47.80 \%$ between the highest dose and absence of wood ash application, respectively.

Application management was significant only in the second and third evaluations. Highest numbers of leaves were found in the management without incorporation, 1855 and 1060 leaves $\mathrm{m}^{-2}$, against 701 and 610 leaves $\mathrm{m}^{-2}$ in the management with incorporation, in the second and third evaluations, respectively. Wood ash application positively influenced the number of leaves of Marandu grass in all evaluations, thus evidencing its potential as alternative fertilizer for pastures under rehabilitation.

In the second year of evaluation, wood ash doses caused significant statistical difference in the number of leaves, which fitted to a quadratic regression model in the first and second evaluations, and to a linear model in the fourth evaluation. The wood ash dose leading to maximum leaf production ( 969.95 leaves $\mathrm{m}^{-2}$ ) was $10.39 \mathrm{Mg} \mathrm{ha}^{-1}$ (Figure 5A) in the first evaluation and $8.62 \mathrm{Mg} \mathrm{ha}^{-1}$ in the second evaluation, with 812.34 leaves $\mathrm{m}^{-2}$ (Figure 5B). In the fourth evaluation, highest wood ash dose $\left(15 \mathrm{Mg} \mathrm{ha}^{-1}\right)$ led to 
Table 1. Plant height of Marandu grass subjected to wood ash doses and application forms, in the third evaluation, in the first year of evaluation. Rondonópolis, MT - Brazil.

\begin{tabular}{|c|c|c|c|c|c|c|}
\hline \multirow{3}{*}{ Forms of application } & \multicolumn{5}{|c|}{ Plant height $(\mathrm{cm})$} & \multirow[b]{3}{*}{15} \\
\hline & \multicolumn{5}{|c|}{ Wood ash (Mg ha $\left.{ }^{-1}\right)$} & \\
\hline & 0 & 3 & 6 & 9 & 12 & \\
\hline Not incorporated & $30.75 b$ & $33.59 \mathrm{~b}$ & $36.166 \mathrm{~b}$ & $35.01 \mathrm{~b}$ & $35.39 \mathrm{~b}$ & $34.91 \mathrm{~b}$ \\
\hline Incorporated & 39.69 a & $44.05 \mathrm{a}$ & $45.75 \mathrm{a}$ & $49.28 a$ & $46.77 \mathrm{a}$ & $55.24 \mathrm{a}$ \\
\hline
\end{tabular}

Means followed by the same letter in the column do not differ by Tukey test at 0.05 probability level.

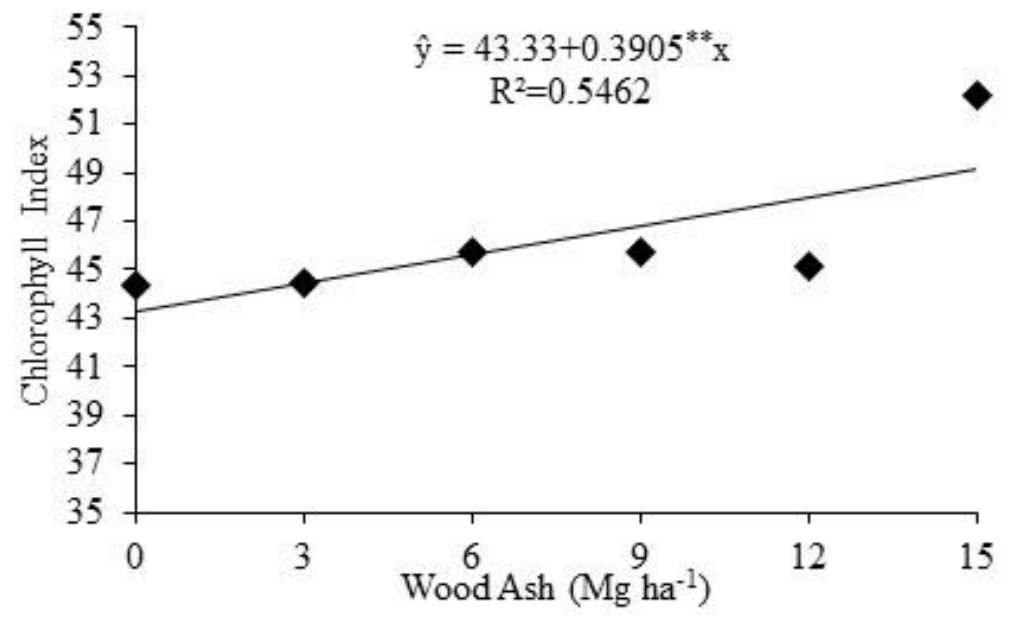

Fig 1. Chlorophyll index $(\mathrm{Cl})$ in the second evaluation of the first year (2015) of Marandu grass rehabilitation using wood ash doses and application forms. Rondonópolis, MT - Brazil. WA=Wood ash, ${ }^{* *}$ significant at 0.01 probability level.

Table 2. Plant height of Marandu grass subjected to treatments with wood ash doses and application forms, in the fourth evaluation, in the first year of pasture rehabilitation, Rondonópolis, MT - Brazil (2015).

\begin{tabular}{lllllll}
\hline \multicolumn{7}{c}{ Plant height $(\mathrm{cm})$} \\
\cline { 2 - 8 } Application forms & 0 & 3 & 6 & 9 & 12 & 15 \\
Not incorporated & $37.30 \mathrm{a}$ & $38.00 \mathrm{a}$ & $38.15 \mathrm{a}$ & $38.78 \mathrm{~b}$ & $37.6 \mathrm{~b}$ & $41.52 \mathrm{a}$ \\
Incorporated & $36.44 \mathrm{a}$ & $40.51 \mathrm{a}$ & $40.07 \mathrm{a}$ & $42.85 \mathrm{a}$ & $44.02 \mathrm{a}$ & $42.06 \mathrm{a}$ \\
\hline
\end{tabular}

Means followed by the same letter in the column do not differ by Tukey test at 0.05 probability level.

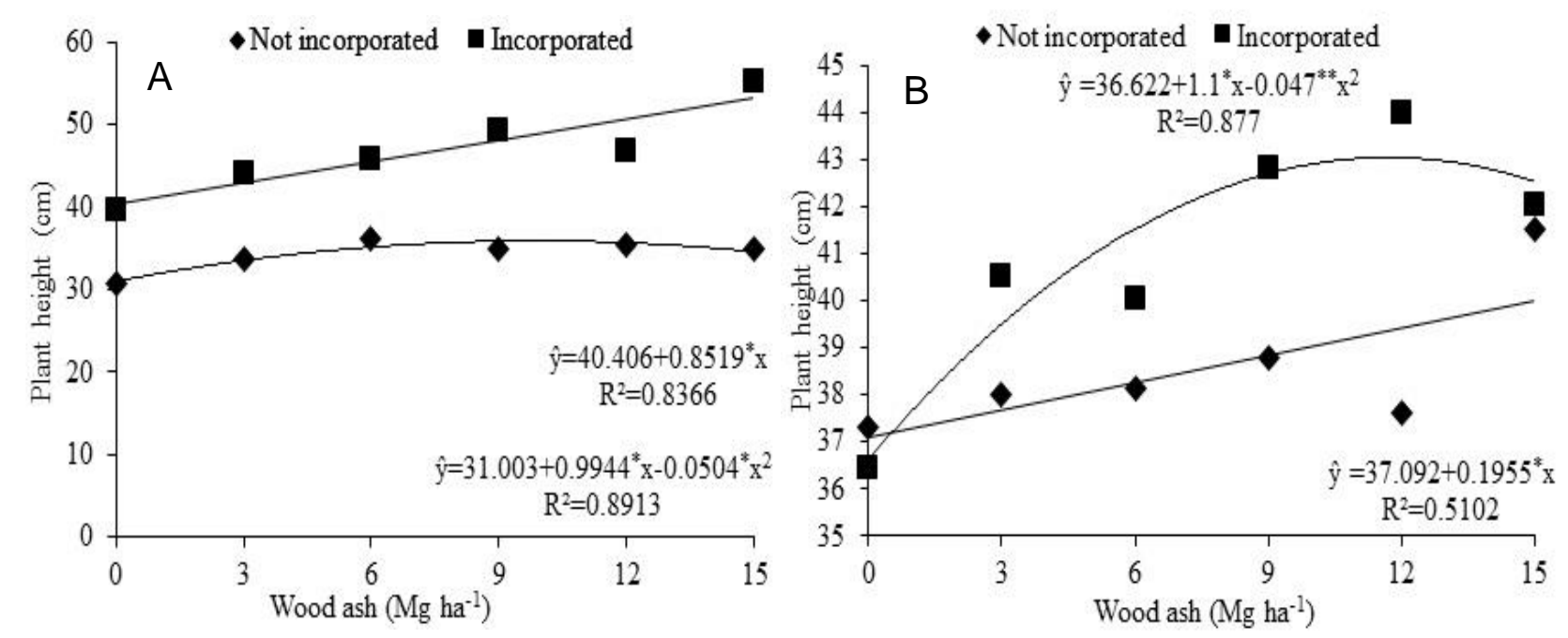

Fig 2. Plant height in the third (A) and fourth (B) evaluation of the first year (2015) of Marandu grass rehabilitation using wood ash doses and application forms. Rondonópolis, MT - Brazil. **, * significant at 0.01 and 0.05 probability levels, respectively. 
Table 3. Plant height of Marandu grass subjected to treatment with wood ash doses and application forms, in the second evaluation of the second year of degraded pasture rehabilitation using wood ash in Rondonópolis, MT - Brazil.

\begin{tabular}{lcccccc}
\hline & \multicolumn{5}{c}{ Plant height (cm) } \\
\hline \multirow{2}{*}{ Application forms } & 0 & 3 & 6 & 9 & 12 & 15 \\
Not incorporated & $14.16 \mathrm{a}$ & $14.96 \mathrm{~b}$ & $15.25 \mathrm{~b}$ & $16 \mathrm{a}$ & $16.67 \mathrm{~b}$ & $17.25 \mathrm{~b}$ \\
Incorporated & $13.29 \mathrm{a}$ & $18.67 \mathrm{a}$ & $19.08 \mathrm{a}$ & $17.96 \mathrm{a}$ & $20.17 \mathrm{a}$ & $20.75 \mathrm{a}$ \\
\hline
\end{tabular}

Means followed by the same letter in the column do not differ by Tukey test at 0.05 probability level.
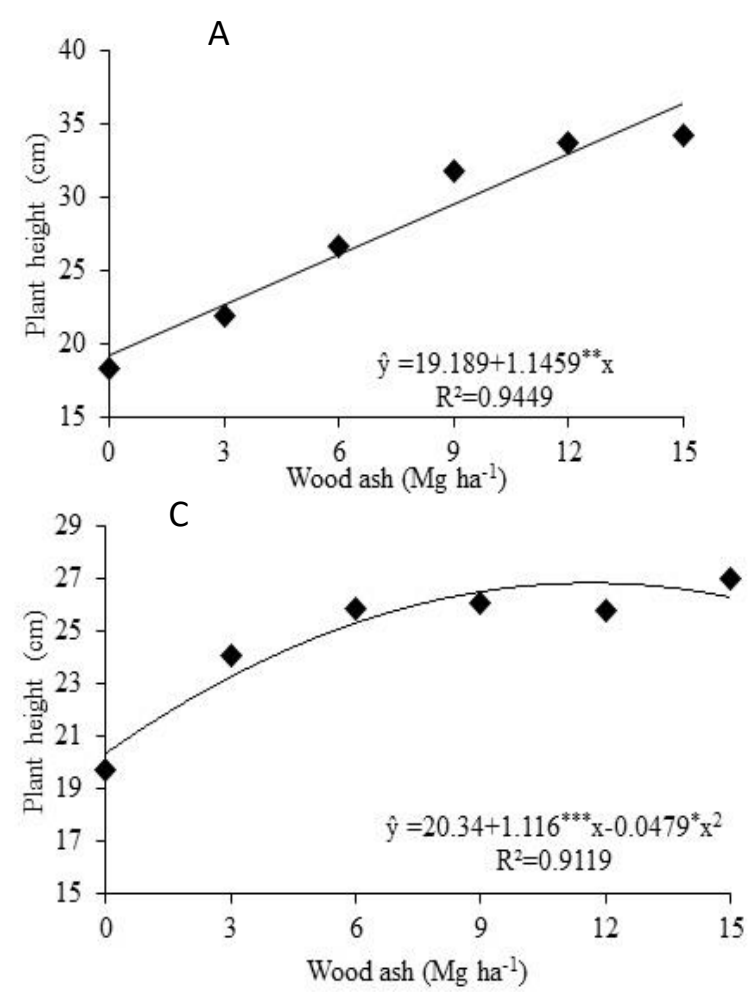
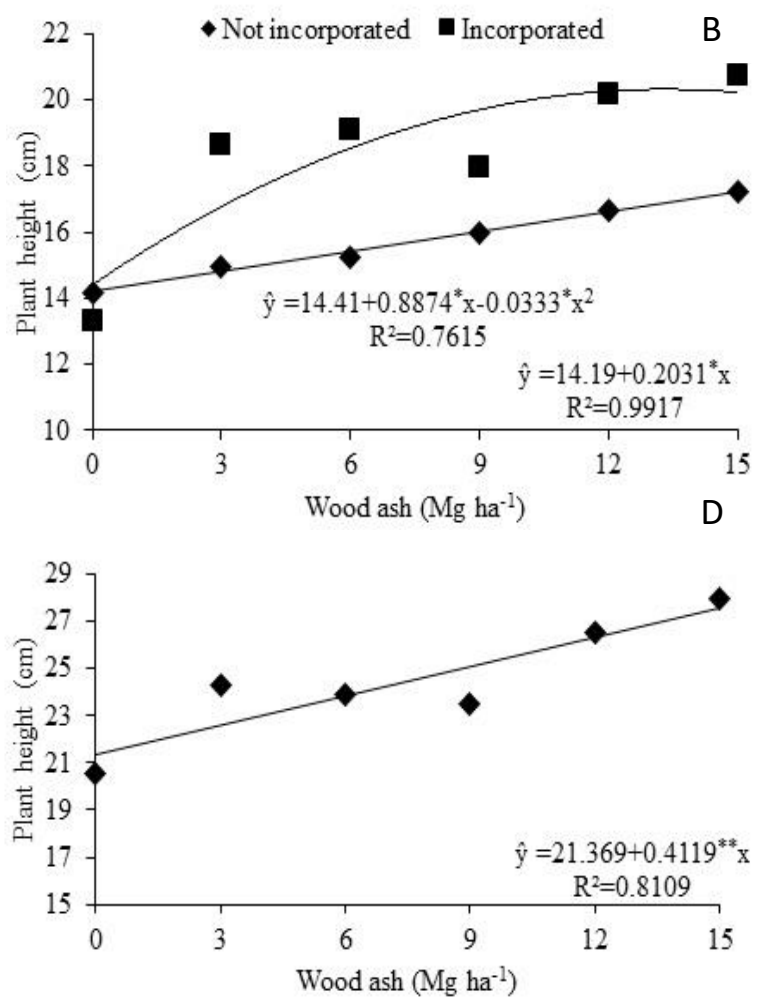

Fig 3. Plant height in the first (A), second (B), third (C) and fourth (D) evaluation of the second year (2016) of Marandu grass rehabilitation using wood ash doses and application forms. Rondonópolis, MT - Brazil. **, * significant at 0.01 and 0.05 probability level, respectively.

Table 4. Chemical and granulometric analyses of Quartzipsamments sampled when the experiment was set up in pasture rehabilitation area. Rondonópolis, Mato Grosso - Brazil, 2014

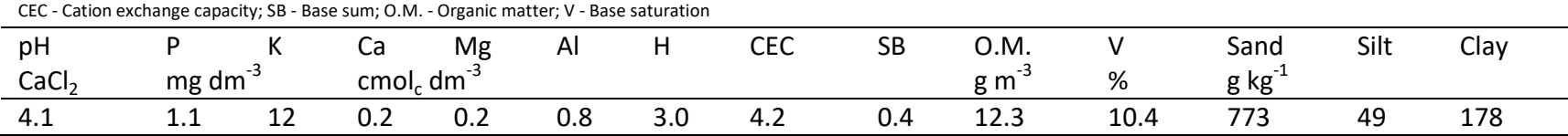

Table 5. Chemical characterization of the wood ash used in 2015 and 2016, respectively

\begin{tabular}{lllllllllll}
\hline Year & $\mathrm{N}$ & $\mathrm{P}_{2} \mathrm{O}_{5}$ & $\mathrm{~K}_{2} \mathrm{O}$ & $\mathrm{Zn}$ & $\mathrm{Cu}$ & $\mathrm{Mn}$ & $\mathrm{B}$ & $\mathrm{Ca}$ & $\mathrm{S}$ & $\begin{array}{l}\mathrm{PN} \\
(\%)\end{array}$ \\
& $\left(\mathrm{g} \mathrm{kg}^{-1}\right)$ & & & & & & & & & \\
\hline 2015 & 2.80 & 29.80 & 33.20 & 0.11 & 0.11 & 0.70 & 0.15 & 31.50 & 1.50 & 20.30 \\
2016 & 3.60 & 3.00 & 4.00 & 0.01 & 0.006 & 0.318 & 0.006 & 1.70 & 0.40 & 7.80 \\
\hline
\end{tabular}

PN - Neutralizing power 

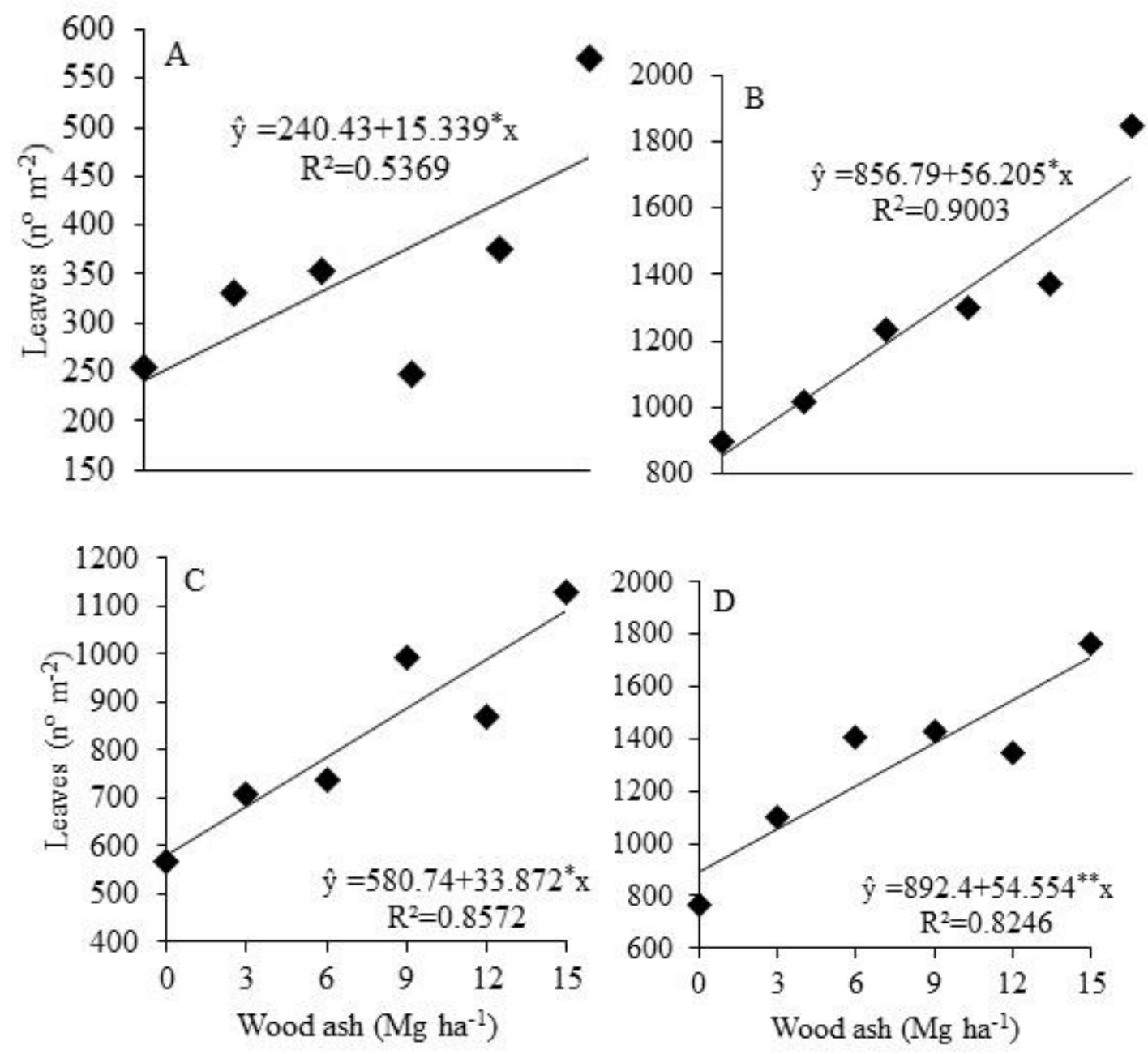

Fig 4. Number of leaves in the first (A), second (B), third (C) and fourth (D) evaluation of the first year (2015) of Marandu grass rehabilitation using wood ash doses and application forms. Rondonópolis, MT - Brazil. **, * significant at 0.01 and 0.05 probability levels, respectively.

highest number of leaves (939 leaves $\mathrm{m}^{-2}$ ), which represents an increment of $48.12 \%$ in comparison to the absence of ash application (Figure $5 \mathrm{C}$ ).

The number of leaves is related to plant structure and is responsible for restoring leaf area and, consequently, to the photosynthetic capacity of forage grasses, besides participating in the maintenance of pasture production (Cunha et al., 2011). Researchers have found higher number of leaves in Marandu grass fertilized with wood ash in Argisol and Latosol (Bezerra et al., 2014).

The interaction between wood ash doses and application managements was not significant for the number of tillers in Marandu grass, with individual effects of doses in the third and fourth evaluations and of application management in the first, second and third evaluations, respectively.

The management without incorporation led to higher number of tillers (494.71 tillers $\mathrm{m}^{-2}$ ) in comparison to that with incorporation ( 73.50 tillers $\mathrm{m}^{-2}$ ) in the first evaluation. In the second evaluation, the same trend occurred, with production of 724.37 and 294.25 tillers $\mathrm{m}^{-2}$ for the managements without and with incorporation, respectively.
Such difference represents an average increase of 427.04 tillers $\mathrm{m}^{-2}$, an increment of $441.51 \%$ in the number of tillers when the management without incorporation was adopted. Significant difference in the number of tillers was caused by wood ash doses. The data fitted to linear regression models, in which the dose of $15 \mathrm{Mg} \mathrm{ha}^{-1}$ led to a total of 434.98 tillers $\mathrm{m}^{-2}$ in the third evaluation (Figure 6A) and to maximum number of tillers ( 597 tillers $\mathrm{m}^{-2}$ ) in the fourth evaluation, an increment of $54.91 \%$ compared with the treatment under no fertilization with wood ash (Figure 6B).

\section{Number of tillers}

In the second year of evaluation, significant difference in the number of tillers was caused by wood ash doses and the data fit to a quadratic regression model in the first evaluation of Marandu grass. The dose leading to maximum tiller production (46.50 tillers $\mathrm{m}^{-2}$ ) was $11.14 \mathrm{Mg} \mathrm{ha}^{-1}$ (Figure 7). In the third cut, significant difference was caused only by the application management, and higher number of tillers (32.62 tillers $\mathrm{m}^{-2}$ ) occurred when wood ash was 

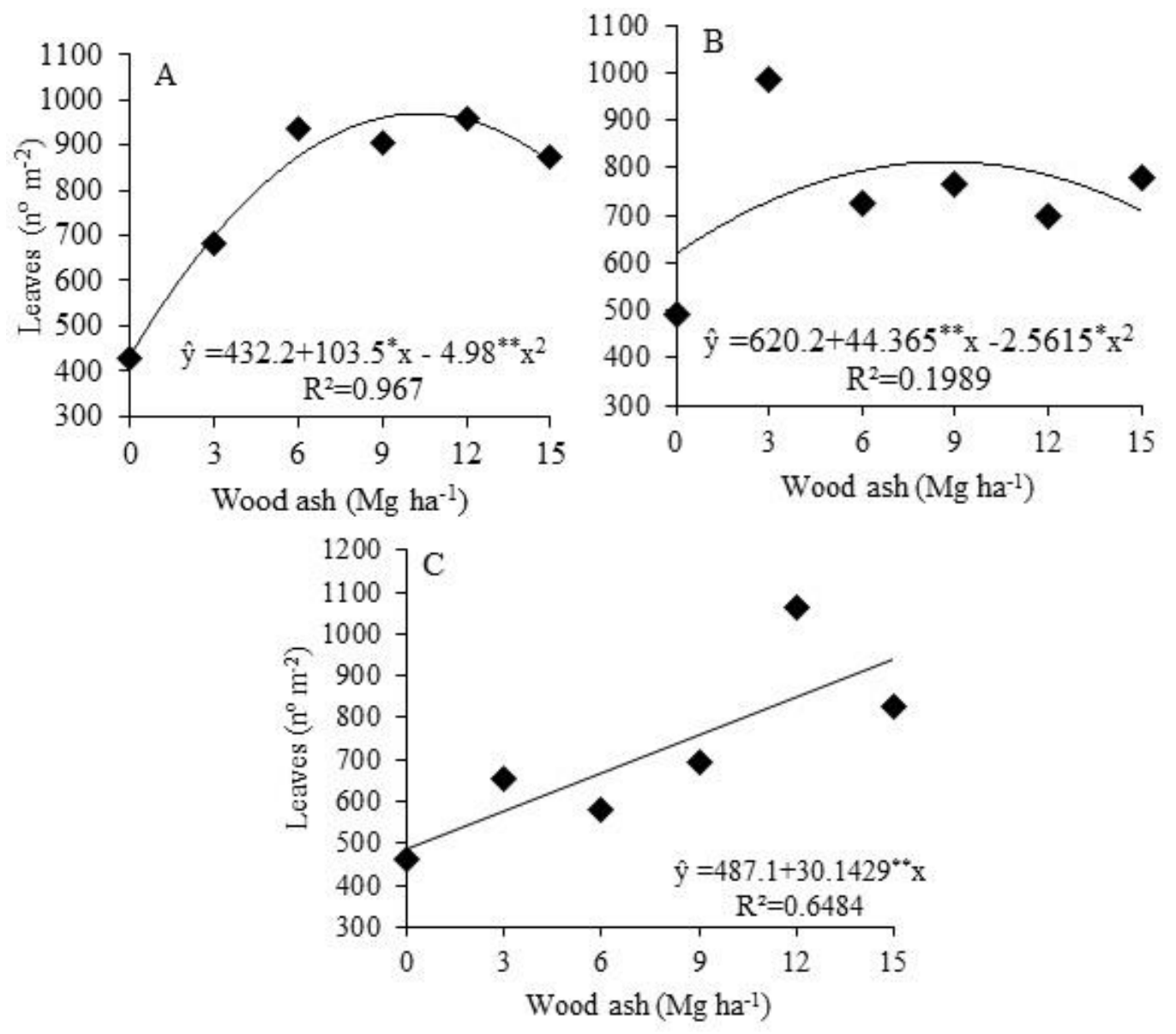

Fig 5. Number of leaves in the first (A), second (B) and fourth (C) evaluation of the second year (2016) of Marandu grass rehabilitation using wood ash doses and application forms. Rondonópolis, MT - Brazil. **, * significant at 0.01 and 0.05 probability levels, respectively.
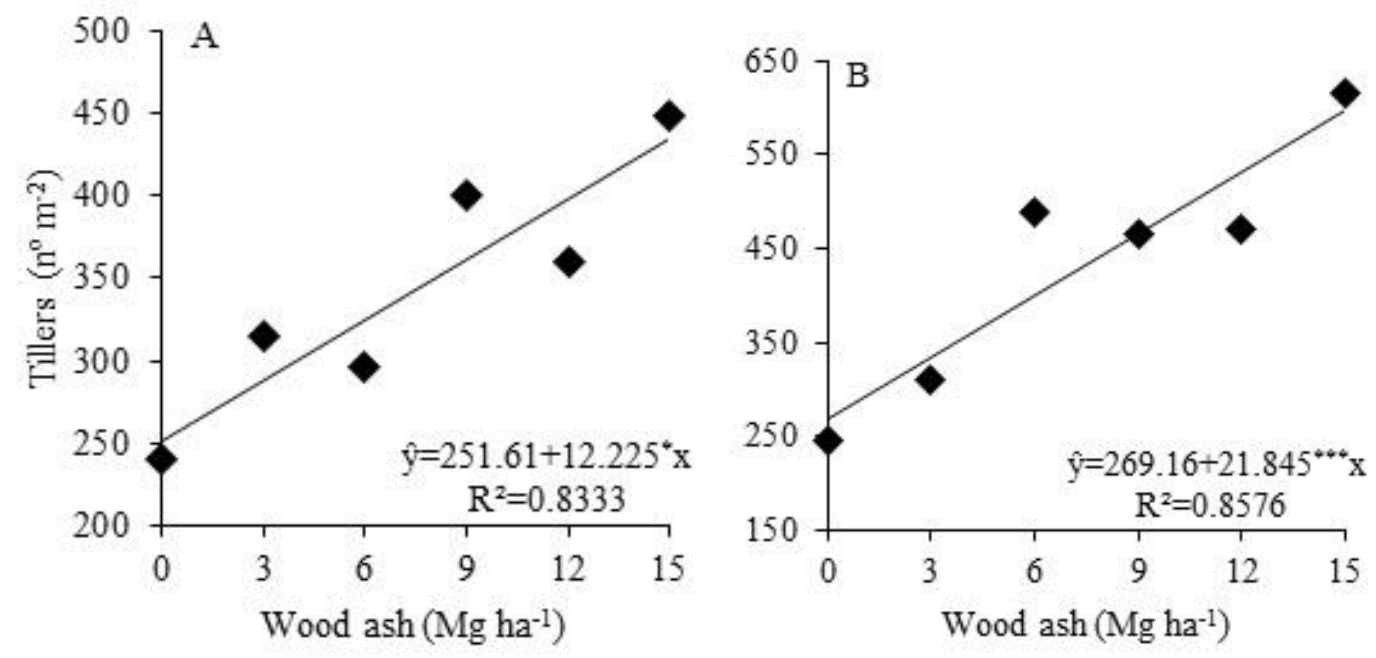

Fig 6. Number of tillers per $\mathrm{m}^{2}$ in the third (A) and fourth (B) evaluation of the first year (2015) of Marandu grass rehabilitation using wood ash doses and application forms. Rondonópolis, MT - Brazil. ***, * significant at 0.001 and 0.05 probability levels, respectively. 


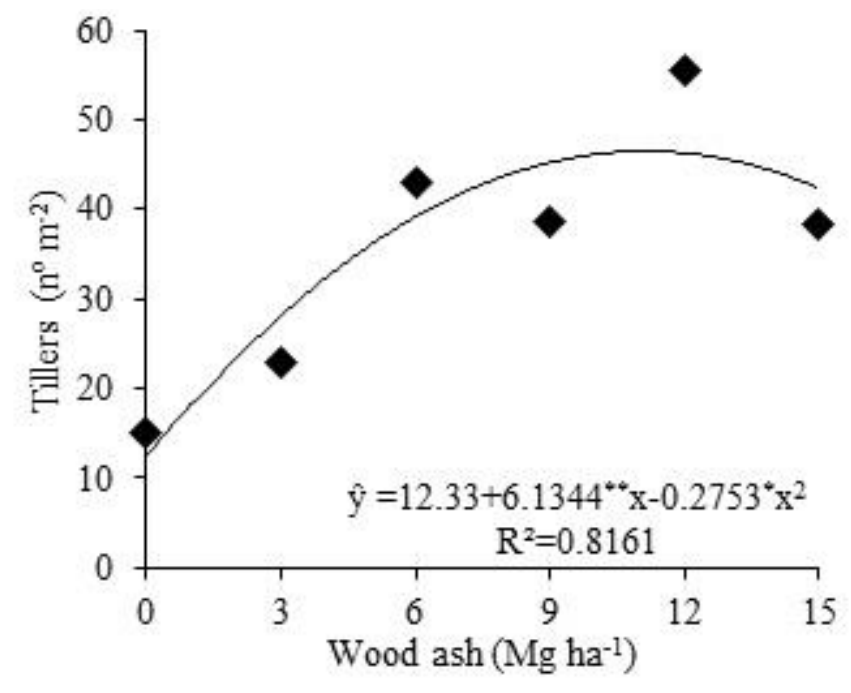

Fig 7. Number of tillers per $\mathrm{m}^{2}$ in the first evaluation of the second year (2016) of Marandu grass rehabilitation using wood ash doses and application forms. Rondonópolis, MT - Brazil. **, * significant at 0.01 and $0.05 \%$ probability levels, respectively.

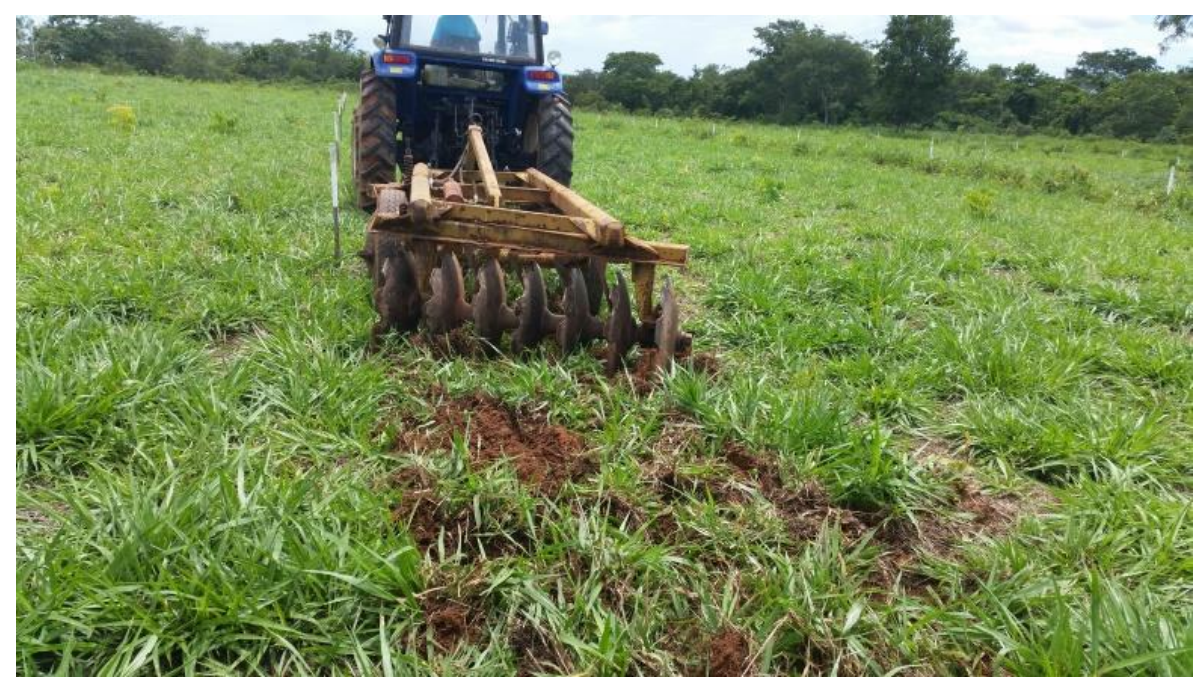

Fig 8. Wood ash incorporation with light-duty disc harrow at $0.20 \mathrm{~m}$ in the subplots that received this treatment on the experiment of Marandu grass pasture rehabilitation using different wood ash doses and application forms.

incorporated, compared with the management without incorporation (17.29 tillers $\mathrm{m}^{-2}$ ).

Tillering of grass species guarantees yield establishment and is positive for their growth and survival in a pasture system (Hodgson, 1990). Studies have pointed to a linear response in the number of tillers of Marandu grass as a function of wood ash doses (Bonfim-Silva et al., 2011) and other cultivars of the genus Brachiaria (Bonfim-Silva et al., 2015).

Studies on pasture rehabilitation systems in soil of the Cerrado region in Mato Grosso have demonstrated the influence of soil management on tiller production and have shown that, over the cultivation years, the management with no soil turning led to higher tiller production in comparison to that with turning of the superficial soil layer (Bonfim-Silva et al., 2010).

Management is essential for the good development of forage grasses. Any decision must be taken with maximum theoretical support because management corresponds to almost $50 \%$ of the contribution to pasture degradation, according to a case study on pasture degradation in China between the years 1982 and 2010 through remote sensing. Climate conditions are responsible for the other half of damages caused to pastures (Zhou et al., 2017). Although the cultivars of the genus Brachiaria show a certain rusticity, stress caused by long water deficits may result in reduction of yield (Kroth et al., 2015). Therefore, it is fundamental to adopt managements that supply organic matter to the soil and favor greater retention of water and nutrients.

The current management adopted by livestock farmers, without liming or fertilization, needs to be rethought because it accelerates the degradation of pasture and soil, contributing to the acceleration of erosive processes, lower water retention and loss of nutrients (Rocha Junior et al., 2017). 
As an alternative management, depending on the investment capital of each farmer and availability of wastes and machinery, wood ash can be used because it positively influences the development of biometric parameters in forage grasses.

\section{Materials and methods}

\section{Study site}

The study was carried out in an area belonging to the Cotton Institute of Mato Grosso (IMA), geographically located at $16^{\circ}$ $33^{\prime} \mathrm{S}$ and $54^{\circ} 37^{\prime} \mathrm{W}$, at altitude of $314 \mathrm{~m}$, between December 2014 to June 2016. The local climate is Aw tropical, according to Köppen's classification, with dry winter and rainy summer (Alvares, 2013), the mean annual rainfall is $1500 \mathrm{~mm}$ and temperature is $24.8{ }^{\circ} \mathrm{C}$. The soil in the experimental area was classified as Quartzipsamments (EMBRAPA, 2013; Soil Survey Staff, 2014). Chemical and granulometric analyses of the soil in the $0-0.20 \mathrm{~m}$ layer, according to EMBRAPA (1997), are presented in Table 6.

Total rainfall in the first evaluation was $865.30 \mathrm{~mm}$ with monthly mean of $123.61 \mathrm{~mm}$, and mean air temperature was equal to $25.90^{\circ} \mathrm{C}$ in this period. In the second year, total cumulative rainfall was $590.50 \mathrm{~mm}$ with monthly mean of $84.36 \mathrm{~mm}$, whereas mean air temperature was $27.13^{\circ} \mathrm{C}$.

\section{Experimental field design}

The experimental area $\left(8400 \mathrm{~m}^{2}\right)$ had been cultivated with degraded pasture of Brachiaria brizantha cv. Marandu for eleven years, without any management until the beginning of this experiment, with low yield and quality of the grass (uncovered soil) and presence of weeds. A randomized block design was used, in $6 \times 2$ factorial scheme corresponding to six doses of wood ash $\left(0,3,6,9,12\right.$ and $\left.15 \mathrm{Mg} \mathrm{ha}^{-1}\right)$ and two application managements (incorporated to the soil with light-duty disc harrow after application and not incorporated), with four replicates. The main plots of each block $(8 \times 30 \mathrm{~m})$ received wood ash application, whereas the application managements (incorporated with light-duty disc harrow and not incorporated) were evaluated in the subplots $(8 \times 15 \mathrm{~m})$, totaling 24 plots and 48 subplots. The area used for evaluations corresponded to $78 \mathrm{~m}^{2}$ per subplot, disregarding $1 \mathrm{~m}$ on each end.

To standardize the initial experimental conditions, the pasture was cut at average height of $0.15 \mathrm{~m}$ using a mechanical mower, followed by manual removal of the cut material. Wood ash was manually applied broadcast on plot surface and incorporated with light-duty disc harrow at 0.20 $\mathrm{m}$ in the subplots that received this treatment, considering its density for application (Figure 8).

The wood ash used each year had different origins, in the first year of driving it came from the food industry, consisting of eucalyptus wood (Eucalyptus sp.) and other wood residues. In the second year, the vegetal ashes came from the ceramic industry, consisting of rice hull, brachiaria, and other diverse residues. The two vegetal ashes were analyzed as fertilizer obtaining different nutritional values according to the constituent material (Table 6).

Since the wood ash has low $\mathrm{N}$ content, due to volatilization in the burning process (Santos et al., 2014), nitrogen fertilization (100 kg ha ${ }^{-1}$ ) was applied in all subplots, using urea as source, when the experiment was set up and after each cut.

\section{Description of evaluations}

In both evaluation years, four cuts were performed at 30day intervals and the first one occurred 30 days after wood ash application. Three samplings were carried out in each subplot at $5 \mathrm{~cm}$ height, using a $1.00 \mathrm{~m} \times 0.25 \mathrm{~m}\left(0.25 \mathrm{~m}^{2}\right)$ rectangle made of iron bars.

The rectangle was randomly thrown inside the evaluation area of each subplot and biometric evaluations were carried out within the delimited area: chlorophyll index, plant height, number of leaves and number of tillers. Chlorophyll index was determined using a SPAD-502 chlorophyll meter, based on 10 readings in diagnostic leaves $(+1$ and +2$)$, because these leaves determine the mean values of chlorophyll index in grasses.

Plant height was determined by throwing a paper sheet three times in the evaluation area of each subplot and measuring the distance from the soil to its average height. Total numbers of leaves and tillers collected within the area delimited by the rectangle were manually counted and the data were converted to leaves $\mathrm{m}^{-2}$ and tillers $\mathrm{m}^{-2}$.

\section{Statistical analyses}

The variables were analyzed in isolation for each year, since the wood ash used had different origin and composition. The data were subjected to analysis of variance by $F$ test and, when significant, wood ash application management data were analyzed by Tukey test and wood ash doses data were subjected to regression analysis, both at 0.05 probability level. All statistical analyses were carried out using the statistical program SISVAR (Ferreira, 2011).

\section{Conclusion}

Highest influence of wood ash doses on the biometric parameters evaluated, plant height, number of leaves and number of tillers, as well as chlorophyll index, was observed between the doses 8 and $15 \mathrm{Mg} \mathrm{ha}^{-1}$, even when there was no significant difference. For the application management, highest value of plant height was caused by wood ash incorporation using a light-duty disc harrow (0-0.20 m), whereas the management without incorporation led to highest production of leaves and tillers. The benefits of using wood ash to recover degraded pastures are mainly related to the type of soil, initial conditions of application, pasture degradation level and climatic variability along the cycle, as well as to the management adopted.

\section{Acknowledgements}

The authors extend their gratitude to the Brazilian National Council for Scientific and Technological Development (CNPq), Coordination for the Improvement of Higher Education Personnel (CAPES) for providing them with scholarships, Foundation for Research Support of the Mato Grosso State (FAPEMAT) and Cotton Institute of Mato Grosso (IMA). 


\section{References}

Abreu JBR, Monteiro FA (1999) Marandu grass yield and nutrition in relation to growth stages and nitrogen fertilization. B Indústr anim. 56(2): 137-146.

Alvares CA, Stape JL, Sentelhas PC, Moraes G, Leonardo J, Sparovek G (2013) Köppen's climate classification map for Brazil. Meteorol Z. 22(6): 711-728.

Bezerra MDL, Bonfim-Silva EM, Silva TJA (2014) Wood ash effect on the productive characteristics of marandu grass in cerrado soils. Afr J Agric Res. 9(30): 2339-2344.

Bezerra MDL, Bonfim-Silva EM, Silva TJA, Sousa HHF, Duarte TF, Espirito Santo ES, Pacheco AB (2016) Wood ash on the fertilization of marandu grass in brazilian cerrado soils. Afr J Agric Res. 11: 1504-1510.

Bonfim-Silva EM, Carvalho JMG, Pereira MTJ, Silva TJA (2015) Wood ash in fertilization in plants of cotton in the cerrado oxisol. Encicl Biosf. 11(21): 523-533.

Bonfim-Silva EM, Santos CC, Silva TJA, Scaramuzza WLMP (2014) Concentration of nitrogen, phosphorus and potassium in tropical grasses fertilized with wood ash in cerrado oxisol. Afr J Agric Res. 9(5): 549-555.

Bonfim-Silva EM, Silva TJA, Cabral CEA, Valadares EM, Goldoni G (2011) Morphological and structural characteristics of the maradu grass fertilized with vegetable ash in oxissol of the cerrado. Encicl Biosf. 7(12): 1-9.

Bonfim-Silva EM, Silva TJA, Luz VS, Guimarães SL, Polizel AC (2010) Marandu grass production in recovery systems in cerrado. Encicl biosf. 6(11): 1-8.

Bougnom BP, Niederkofler C, Knapp BA, Stimpfl E, Insam H (2012) Residues from renewable energy production: Their value for fertilizing pastures. Biomass Bioenergy. 39: 290-295.

Costa JAA, Queiroz HP (2013) Régua de manejo de pastagens. Comunicado Técnico 125 - EMBRAPA, Campo Grande - MS.

Cunha FF, Ramos MM, Alencar CAB, Oliveira RA, Araújo RAS, Cecon PR, Martins CE, Cóser AC (2011) Leaf numbers of xaraes grass in different management and rates of fertilization, rest periods and annual seasons. Biosci J. 27(2): 271-282.

EMBRAPA (1997) Manual de métodos de análises de solo, $2^{\text {nd }}$ edn. Embrapa Solos, Rio de Janeiro. 212.

EMBRAPA (2013) Sistema brasileiro de classificação de solos, $3^{\text {rd }}$ edn. Embrapa Produção de Informação, Brasília. 412.

Ferreira DF (2011) Sisvar: a computer statistical analysis system. R Ciênc Agrotec. 35(6): 1039-1042.

Fonte SJ, Nesper M, Hegglin D, Velásquez JE, Ramirez B, Rao IM, Bernasconi SM, Bünemann EK, Frossard E, Oberson A (2014) Pasture degradation impacts soil phosphorus storage via changes to aggregateassociated soil organic matter in highly weathered tropical soils. Soil Biol Biochem. 68: 150-157.

Hernández Garay A, Matthew C, Hodgson J (1997) Effect of spring grazing management on perennial ryegrass and ryegrass-white clover pastures. Tiller and growing point densities and population dynamics. New Zeal J of Agric Res. 40: 37-50.
Hodgson J (1990) Herbage production and utilization. In hodgson J (ed) Grazing management: science into practice, $1^{\text {st }}$ edn. Wiley, New York. 203.

Huotari N, Sutela ET, Moilanen M, Laiho, R (2015) Recycling of ash - for the good of the environment? Forest Ecol Manag. 348: 226-240.

Kroth BE, Bonfim-Silva EM, Silva TJA, Koetz M, Schlichting AF (2015) Brachiaria brizantha cultivars grown under different water availability in entisol. R Bras Eng Agríc Ambient. 19(5): 464-469.

Lavres Júnior J, Monteiro FA (2006) Nitrogen nutritional status in aruana grass in a controlled environment. Rev Bras Ciênc Solo. 30(5): 829-837.

Martha Júnior GB, Vilela L (2002) Pastagens no cerrado: baixa produtividade pelo uso limitado de fertilizantes. $1^{\text {st }}$ edn. Embrapa Cerrados, Planaltina.

Nesper M, Bünemann EK, Fonte SJ, Rao IM, Velásquez JE, Ramirez B, Hegglin D, Frossard E, Oberson A (2015) Pasture degradation decreases organic $P$ content of tropical soils due to soil structural decline. Geoderma. 257: 123-133.

Nunes SG, Book A, Penteado MI, et al. (1985) Brachiaria brizantha cv. marandu. 2nd edn. Embrapa Gado de Corte, Campo Grande. 31.

Qin J, Hovmand MF, Ekelund F, Ronn R, Christensen S, Groot GA, Mortensen LH, Skov S, Krogh PH (2017) Wood ash application increases $\mathrm{pH}$ but does not harm the soil mesofauna. Environ Pollut. 224: 581-589.

Rocha Junior PR, Andrade FV, Mendonça ES, Donagemma GK, Fernandes RBA, Bhattarai R, Kalita PK (2017) Soil, water, and nutrient losses from management alternatives for degraded pasture in brazilian atlantic rainforest biome. Sci Total Environ. 583: 53-63.

Salisbury FB, Ross CW (1992) Plant physiology, $4^{\text {th }}$ edn. Wadsworth Publishing Company, California. 682.

Santos CC, Bonfim-Silva EM, Silva TJA (2014) Tropical grass fertilized with wood ash in cerrado oxisol: concentrations of calcium, magnesium and sulphur. Afr J Agric Res. 9(19): 1495-1501.

Soares Filho APS (2010) Nutrient absorption of brachiaria brizantha and the weed urena lobata as influenced by ph. Revista Planta Daninha. 18: 443-450.

Soil Survey Staff (2014) Keys to Soil Taxonomy. USDA Natural Resources Conservation Service, Washington.

Zhou W, Yanh H, Huang L, Chen C, Lin X, Hu Z, Li J (2017) Grassland degradation remote sensing monitoring and driving factors quantitative assessment in China from 1982 to 2010 . Ecol Indic. 83: 303-313. 